\title{
Towards Establishing Financial and Budget Indicators for Municipalities: Theoretical
} Approach

\author{
Mirjana Sejdini \\ EPOKA University \\ msejdini@apoka.edu.al
}

\begin{abstract}
Currently, one of the main problems that municipalities and other stakeholders face is having some objective indicators related to the finances and particularly the budget of municipalities in the Republic of Macedonia. Considering the nature of local government finances of the municipalities and consulting various previous studies carried in similar countries like Macedonia, it is possible to generate some representative financial or budget indicators that could apply to municipalities in the country. These indicators would serve as the basis on which municipalities could be ranked within a year or through various years dependent on the availability of the data aiming at analyzing their relative performance and positioning. This paper aims at consulting the literature about generating these indicators and analyzing their applicability in the case of municipalities in Macedonia. The output of this study is a set of financial or budget indicators related to revenues and expenditures in municipalities of Macedonia. Definitely, this is a pioneering study for the country and the region. It would contribute to the existing research about evaluating the financial relative performance and financial conditions of municipalities not only in Macedonia, but also in the region.
\end{abstract}

Keywords: Financial Indicators, Budget Indicators, Municipalities,

\section{Introduction}

The existing literature review will serve the purpose of identifying the most representative indicators that can measure the performance of local government units. As such, it starts with the definition, characteristics and approaches to indicators and their development into a system of indicators. Furthermore, it offers a framework that can be applied in the context of the financial performance of local government units in Macedonia.

Developing a System of Indicators

Before generating a system of indicators used to assess certain performance it is important to go through some basic definitions and characteristics of the term "indicator". Then, one can easily go through a process of generating a whole system of indicators.

Generally, when developing certain indicators it is very important to consider a multidimensional approach so that these indicators become the most representative in measuring or assessing the situation or problem for which they are designed. This multidimensional approach then, it is adapted to the context of the situation that they are going to measure. This is the guiding principle in moving towards establishing the financial and mainly budget indicators that could be used to measure the relative performance of municipalities (LGUs) in the Republic of Macedonia.

\section{Defining Indicators}

Defining the indicators gives the starting of understanding the importance of indicators in assessing a certain context. Their definition is complete if it is offered with indicators' various characteristics. It is important to note that most of the definitions regarding the term indicator come from practitioners reports produced for the purpose of evaluating a program or a project. However, such definition is backed by those given in the scholarly literature.

Indicators may be quantitative or qualitative benchmarks that provide a simple and reliable basis for assessing achievement, change or performance (Church \& Rogers, p. 44). Quantitative indicators are expressed with sums or quantities, while quantitative indicators are expressed through people's judgements or perceptions about what is measured. They represent means of analyzing and monitoring the characteristics of operations, services and processes, and their implementation. in addition, they can also be used to measure, monitor, evaluate and improve performance (IOM, 2008, $p$. 8); (SFCG, p. 6); (MDF, 2005, p. 1). However, in line with 'qualitative/quantitative' debate, indicators can be defined for the so-called qualitative aspect; because there is always a way of measuring quality if it is clearly defined (Martin \& Sauvageot, 
2011, p. 31). for example, one can measure the quality of spending in an LGU, by specifying its meaning. If it means that expenditures of an LGU are prioritised than spending on $X$ type of expenditure category can be assigned with a certain weight. Ultimately, both types of indicators are very important, especially when they are combined, because qualitative indicators quite often provide more appealing information on how something happens and why it happens (SFCG, p. 7); (Mujeri, p. 3). Another related concept of indicators, considered from a managerial approach though, is given by Victoria (2010) in the form of Key Performance Indicators which are quantitative and qualitative measures used to review an organisation's progress against its goals, extracted in form of targets for achievement by departments and individuals.

An indicator can be a number, an observation or a signal that gives us a reliable and unbiased understanding about an object, a situation, a phenomenon, a happening, a motion, a development process, etc. (UNESCO, 2000). On the other hand, indicators are imperfect and vary in validity and reliability (Church \& Rogers, p. 44).

An indicator is not raw data, meaning that a budget report at the end of the year is not a list of indicators that can be used to evaluate the financial status of an LGU. in contrast, indicator (s) represents a synthesis or composition of data in the form of percentages, ratios and indices. in the case of LGU finances it could be the ration of own revenues to the total revenues generated at the end of an ending budgetary year. Additionally, an indicator is different from an objective. It is rather converted from an objective, which is logical because an indicator has to serve a purpose or specifically an objective on which it is attached (Martin \& Sauvageot, 2011, p. 35).

An indicator is synonymous with measuring meaning it can be in the form of a value, characteristic used to monitor the performance of a program, service, organization, or access a condition (NPMAC, 2010, p. 45).

An indicator is a factor or variable that provides a simple and reliable means to reflect changes. An indicator enables us to perceive the differences, improvements or developments relating to a desired change (output, objective, and goal). The term indicator is compatible with such terms as performance indicator, performance measure, indicator of success, and indicator of change. (SFCG, p. 4).

\section{Characteristics of Indicators}

The various characteristics of indicators would provide insight in understanding the nature and use of indicators themselves. in addition, they can provide a platform of criteria that can be used to assess the validity of a chosen indicator.

An indicator can be applied in various contexts and fields (SFCG, p. 4). Therefore, there can be social indicators, political indicators, economic indicators, development indicators, education indicators, performance indicators, financial indicators, local government indicators, local government financing indicators, budgetary indicators, and so on. Whenever, there is a study measuring performance in the above-mentioned contexts and areas, there is a high likelihood of using their respective indicators.

An indicator is created for a purpose depending for which it is developed. (Martin \& Sauvageot, 2011). Indicators are not methodological tools, but they are generated from the general overview of the system that they are supposed to measure. in other words, deciding on which indicators you will use it is quite political before it becomes methodological. in case of analysing the budgets of LGUs one purpose could be to determine the ability of an LGU to generate its own sources. However, such an indicator should have the commitment of the Mayor, due to its sensitive nature in judging the Mayor's success.

Depending on the availability of the data, the indicators can be direct, meaning they describe the subject that is measured (the number of employees in a municipality) or indirect requiring to choose a proxy instead. in the case of local government units, it is difficult to find data collected for each of the specific services of municipalities for all LGUs in Macedonia. Therefore, there is a tremendous need for using proxy. for example, instead of having as an indicator of LGUs service the number of people who do not have water 24 hours per day and knowing that more or less all inhabitants of a municipality more or less share the same level of service in terms of its quality, then the number of inhabitants in the municipality could be taken as a proxy indicator.

SMART Indicators. Related to the common formula used in management related to objectives, goals, targets and even indicators, it is important that our concerned indicators be SMART. More specifically and in the context of their financial nature of LGUs, they should be specific, measurable, attainable, results-oriented and time-framed. Indicators should be specific enough to refer to a particular budgetary item or service provision and its extent, including quality if possible. This can be referred as "validity". Indicators can be measured quantitative or qualitative and data should either exist, or can be collected. in addition, measurability means that indicators should not be ambiguous. Attainable (Achievable/Feasible) 
indicators are realistically possible to achieve the determined performance target and they can be collected. Resultsoriented (relevant) indicators should reflect the status of performance and yet allow for progress judgement achievement until $100 \%$. in other words, they must provide effective information for programmes objectives. Time-framed (timebound/time-framed) indicators should reflect sense of time, over which the targets are expected to be met. Collection and reporting of the indictors should be in the right time. The above SMART components fit into the approaches followed by (UNDP, 2002); (MDF, 2005); (UNICEF); (MLE, 2013); (IOM, 2008, p. 17); (AC4SC, 2011, pp. 4-5); (MDF, 2005, p. 5)

SPICED Indicators. Another similar formula for defining indicators is SPICED for Subjective, Participatory, Interpreted, Communicable and Empowering, Cross-checked and Compared, and Disaggregated and Diverse. Subjective indictor means using informants for their unique insight, which becomes critical data because others see it as anecdotal. Participatory indicators are the ones that are developed with the input of those that will assess and use them. Interpreted and Communicable indicators need further explanation to other stakeholders. Cross-checked and Compared indicators allow for comparing different indicators and progress and use various informants, methods, or researchers. Indicators should be Empowering in their nature so that their users reflect critically on their changing context. (AC4SC, 2011, pp. 56); (SFCG, p. 10); (MDF, 2005, p. 5)

The difference between SMART and SPICED indicators is that the first describes the properties of the indicators themselves, while SPICED relates more to how indicators should be used (SFCG, p. 4). Additionally, SPICED approach due its highly qualitative and descriptive nature is best used for participatory monitoring and evaluation, while SMART approach is used mainly in measuring due to their quantitative nature. However, for indicators to be mostly representative and valid, they should comply to both of the above formulas. Other studies give a long list on the characteristics of indicators which exhaust these formulas such as Public Record Office of Victoria guideline in establishing KPIs (Victoria, 2010).

To summarize, indicators are inevitable to establish a performance assessment. They are applied in various areas, meaning they are not exhaustive to a particular are. However, they have certain characteristics and various contexts of applications which serve as a guideline to choose a particular indicator over the other.

\section{Various approaches to developing indicators}

Depending on the nature of the process, for which one designs a certain number of indicators, one may follow a variety of approaches. It is very important to note all of the approaches have something in common. They reflect the whole process but with a different number of phases. One may have a 5-step approach; another one may have a 10-steps approach, depending on the detailed information and the level up to which there is a representing category of indicators.

Indicators in the project or programme cycle. The function of such indicators would be used along the various phases (identification, formulation, implementation, monitoring, and evaluation) of the project or programme (MDF, 2005, pp. 2-3) and as such it is expected that they would differ. Typically, one would have indicators for identification phase such as indicators for analysing the budget statement items related to the other LGUs. An example could be whether the Head of Commission for Finance within the Municipality Council provides information for budget statement by comparing it with other like municipalities.

Indicators can be used in relation to the baseline (Church \& Rogers, p. 45) (efficiency and effectiveness) and to the financial execution (outputs, result and outcomes) (DGFARD, 2006, p. 7). Baseline indicators may be objective related when they are linked with the wider objectives or aims of the programme/project, or they may be context related if they offer information on the particular aspects of the general context on which the programme/project is developed.

Steps in formulating indictors profoundly should answer questions like: What, How Much, Who, Where, and When. (MDF, 2005). What means generating variables of the subject matter during which a minimum standard should be considered. in the context of LGU finances these questions would take the form of: What would be the definition of financial or budgetary performance indicators used to evaluate municipality performance? How much would refer the magnitude of change expected to be achieved. Who refers do defining the target group involved in the assessment. Where - defines further the specific information on the intervention area. When would be related to defining the timeframe of the assessment itself.

A ten-step approach in developing an indicator system by (Martin \& Sauvageot, 2011, p. 31) consists of (1) identifying objectives; (2) creating a policy list based on these objectives; (3) developing a list of indicators; (4) listing the data required to calculate the indicators; (5) locating the data sources available; (6) Calculate the indicators; (7) verify the results; (8) analysing the indicators; (9) selecting the final indicators for the system; and, (10) selecting the layout of the indicator system document. 
Another approach to developing indicators pertaining more to the financial performance is a multi-step approach that starts (1) convening of an expert panel that would further (2) select the dimensions of the financial performance. Then this would be combined with (3) the review of the literature on this aspect of performance, followed by (4) selection of the indicators. These (5) indicators later are defined and (6) data are assigned to them. Last steps allow for (7) analysing the data and (8) providing results.

Diagram 1: A Model for Analysing the LGUs Financial Performance

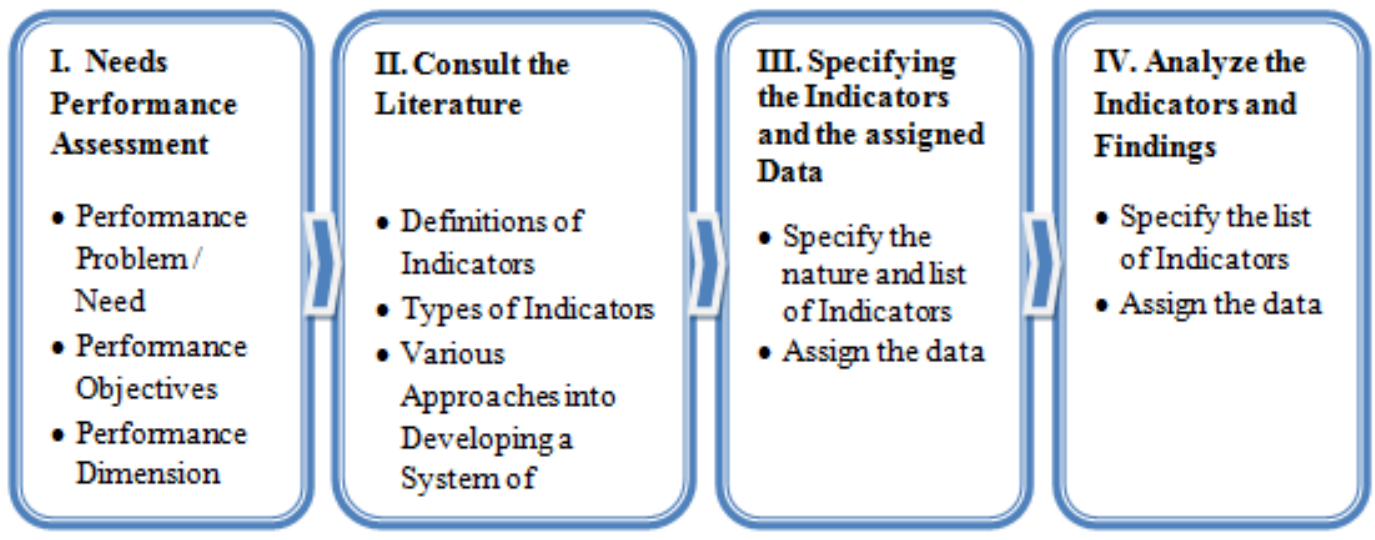

Source: Own work

\section{Financial Indicators for LGUs}

This section will elaborate further in the steps of the generated model (see Diagram 1) of developing a system of indicators for measuring the financial (mainly budgetary) performance of LGUs in Macedonia. Therefore it will give the particularities or the context of the need to develop indicators in the first place. Then it will follow with the additional part of literature review of defining indicators, showing their main characteristics and some approaches to their development, which started in the first section of this paper. This extended literature will provide the foundation out of which the financial indicators may be extracted. The final part of the paper shows the list of the specific indicators that later on (in another paper) will be assigned with their related data and provide an assessment of LGUs financial performance.

\section{The Context of financial indicators}

The context of financial indicators is determined by the nature of the performance assessment in the first place. Therefore, one cannot generate a list of indicators unless the context of their application is specified. in this case, it is of a paramount importance to identify the principle based on which the budget performance is evaluated. By referring to the recommended budget practices outlined by GFOA (USA) there are four principles which serves as a framework for improving budgeting at both, central and local government level (GFOA, 2000):

Principle I - Establish Broad Goals To Guide Government Decision Making

Principle II - Develop Approaches to Achieve Goals

Principle III - Develop a Budget with Approaches to Achieve Goals

Principle IV - Evaluate Performance and Make Adjustments

The fourth principle stresses the need for program and financial performance that should be continually evaluated, and the need for adjustments to encourage progress toward achieving goals. (GFOA, 2000). The general practices that come out of this element of the fourth principle include monitoring, measuring and evaluating performance, budgetary performance, financial condition, external factors and capital program implementation.

Furthermore, the budgetary performance assessment can be either for the central government or local government budgets. in this case the interest is on the LGUs financial performance. Therefore the indicators have to be extracted mainly 
by the financial statements (mainly budget) of LGUs in Macedonia. The list of indicators will represent all of the LGUs because all of them has the same preparation of the budget and same reporting methods.

\section{Classification of performance indicators}

In general, there are two groups of performance indicators: financial and non-financial indicators (Wilson, 1999) pg 50). The first category of indicators measures the costs of offering the services, while the second category measures the quality of delivering public services. The first group can measure: total costs per LGU employee, total costs per a Council Member, total costs per a pupil, etc. The second group can measure: percentage of people legalizing their property, percentage change of pupil yearly average grade, percentage change of people complaining about cutting water supply, etc.

According to (Wilson, 1999, p. 171); (Liu, Chen, Mingers, \& Q Li, 2009); (Jackson, 2012) and other public finance and management books, 'Value for money' (VFM) is achieved when one organization has reached its maximum value within a given structure of resources, or, if it has succeeded in the 'three 3 Es' - Economy, efficiency and effectiveness. Economy refers to rational use of resources in terms of saving expenses, time or efforts. Efficiency implies reaching the same level of output or services for less input - expenses, time or efforts. in other words, it means 'doing things in the right way'. Effectiveness refers to delivering better level of output or services for the same level of input - expenses, time or efforts. in other words it means 'doing the right things'. Currently, the forth $\mathrm{E}$ - equity - should be taken in account, as well. Equity refers to fairness and justice of processes and outcomes for all.

(Jorge, Camoes, Carvalho, \& Fernandes, 2006) summarise public sector management indicators, according to their criteria of classification (see Table 1) in relation to nature, the object to be measured, the information needed and according to their scope, which overlap with the previous classification of the indicators, above. Related to the VFM indicators, Jorge, et. al (2006) adds the fourth and fifth Es - Equity and Excellence, with the last referring to fairness and justice of processes and outcomes for all.Table 1 Classification of Public Sector Management Indicators

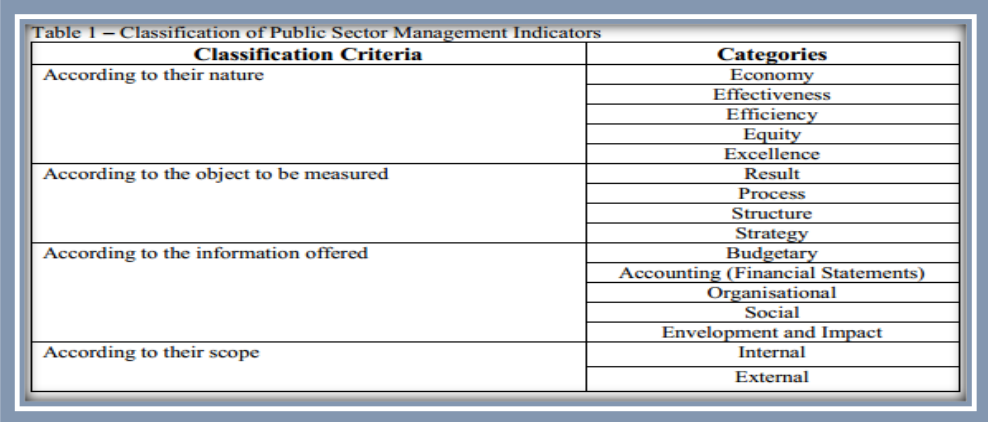

Source: (Jorge, Camoes, Carvalho, \& Fernandes, 2006)

Diagram 2: Modelling local sector production process

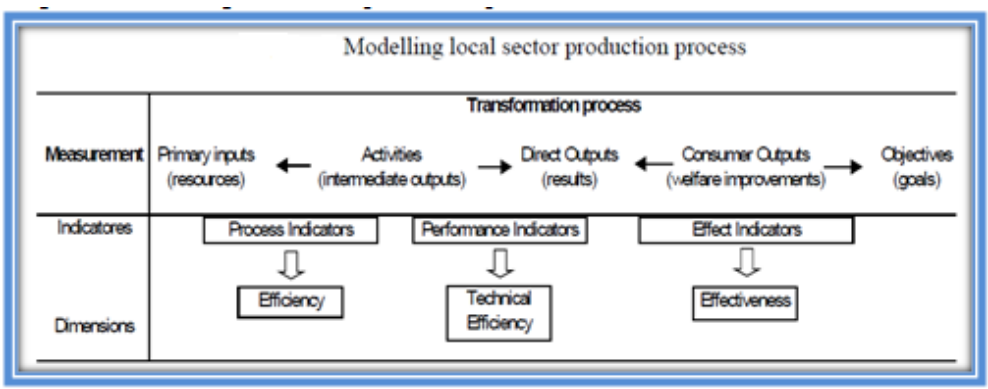

Source: (Afonso \& Fernandes, Efficiency of Local Government Spending: Evidence from Lisbon Region, 2003) 


\begin{tabular}{|c|c|c|c|}
\hline 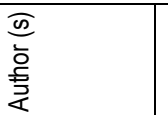 & 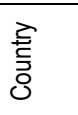 & Input Indicators & Output Indicators \\
\hline 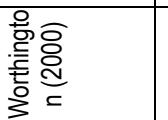 & 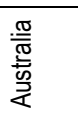 & $\begin{array}{l}\text { Number of full-time equivalent } \\
\text { employees, } \\
\text { other physical expenses, financial }\end{array}$ & $\begin{array}{l}\text { Population, properties receiving domestic waste management } \\
\text { services, sewerage services and water services, } \\
\text { length of urban and rural roads }\end{array}$ \\
\hline 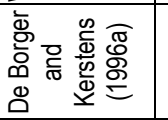 & $\frac{\Xi}{\bar{D}}$ & Total expenditures & $\begin{array}{l}\text { Number of beneficiaries of minimal subsistence grants and } \\
\text { students enlisted in local primary schools, } \\
\text { surface of public recreation facilities, }\end{array}$ \\
\hline 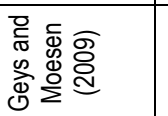 & 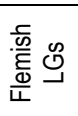 & Total Current expenditures & $\begin{array}{l}\text { Number of subsistence grants and students in local primary } \\
\text { schools, } \\
\text { surface of public recreational facilities, }\end{array}$ \\
\hline 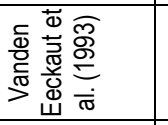 & 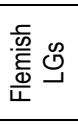 & Total expenditures & $\begin{array}{l}\text { Length of municipal roads, Number of subsistence grants and } \\
\text { students in local primary schools, } \\
\text { total population, }\end{array}$ \\
\hline 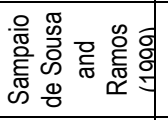 & $\underset{\overline{\mathbb{N}}}{\bar{\oplus}}$ & Current spending & $\begin{array}{l}\text { Total resident population, domiciles with access to safe water, } \\
\text { domiciles served by garbage collection, } \\
\text { illiterate nonulation enrolment in nrimary and secondarv }\end{array}$ \\
\hline 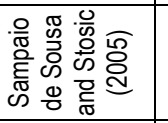 & $\underset{\bar{N}}{\bar{\pi}}$ & $\begin{array}{l}\text { Current spending, } \\
\text { number of teachers, } \\
\text { rate on infant mortality }\end{array}$ & $\begin{array}{l}\text { Total and literate population, enrolment per school, } \\
\text { student attendance per school, }\end{array}$ \\
\hline 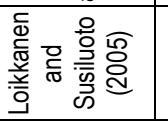 & 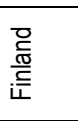 & $\begin{array}{l}\text { Sum of the net operating costs of } \\
\text { providing health and social services, } \\
\text { culture and education (evaluated at }\end{array}$ & $\begin{array}{l}\text { Children's day care centers, } \\
\text { children's family day care, }\end{array}$ \\
\hline 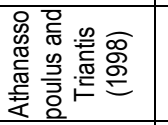 & 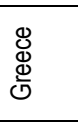 & $\begin{array}{l}\text { Operating costs (expenditures on } \\
\text { services, salaries, maintenance and } \\
\text { material) }\end{array}$ & $\begin{array}{l}\text { Actual households, } \\
\text { average house area, } \\
\text { heavvindustrial use area }\end{array}$ \\
\hline 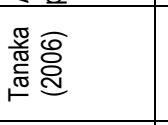 & 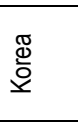 & $\begin{array}{l}\text { Sum of labour, capital and non- } \\
\text { personnel costs }\end{array}$ & $\begin{array}{l}\text { social assistance spending per household, } \\
\text { children per nursery school, } \\
\text { teacher-student ratin }\end{array}$ \\
\hline 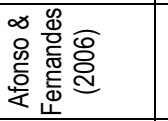 & 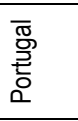 & Total per-capita expenditures & $\begin{array}{l}\text { Calculation of a single municipal performance indicator from } \\
\text { several municipal services }\end{array}$ \\
\hline 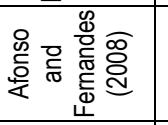 & 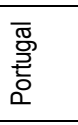 & Total per-capita expenditures & $\begin{array}{l}\text { Calculation of a single municipal performance indicator from } \\
\text { several municipal services }\end{array}$ \\
\hline 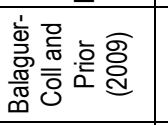 & क्ट & Total expenditures & $\begin{array}{l}\text { Number of lighting points, } \\
\text { population, } \\
\text { waste collected }\end{array}$ \\
\hline 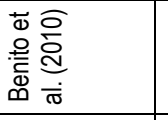 & 产 & $\begin{array}{l}\text { Costs of personnel, } \\
\text { current consumptions, } \\
\text { current transfers }\end{array}$ & $\begin{array}{l}\text { Different output indicators for the following areas of public good } \\
\text { provision: police, culture, sports, green areas, refuse collection } \\
\text { and water supply }\end{array}$ \\
\hline 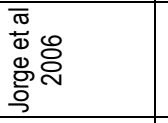 & $\begin{array}{l}\overline{\mathbb{0}} \\
\text { 을 } \\
\text { 능 }\end{array}$ & $\begin{array}{l}\text { Total Expenditure; Personnel } \\
\text { expenditure, Expenditure of goods and } \\
\text { services, capital expenditures }\end{array}$ & $\begin{array}{l}\text { Local inhabitants with } 15 \text { or less years old. } \\
\text { Local inhabitants with } 65 \text { or more years old. } \\
\text { Numher of hasic or elementarv schonls }\end{array}$ \\
\hline 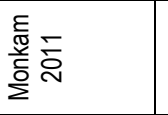 & 产 侻 & Total operating or current expenditure & $\begin{array}{l}\text { the number of consumer units receiving water, } \\
\text { the number of consumer units receiving sewerage and } \\
\text { sanitation, }\end{array}$ \\
\hline 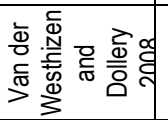 & 秐 它 & $\begin{array}{l}\text { the value of staff costs and total } \\
\text { operational income }\end{array}$ & $\begin{array}{l}\text { the total number of households receiving water, sanitation, } \\
\text { electricity and refuse removal }\end{array}$ \\
\hline
\end{tabular}


Related to the Value for money and 3-5Es concept of evaluation framework, Afonso, et. Al (2003) offers a model or matrix of local production process conceptualising the whole process according to process, performance, and effect indicators.

Another approach to identifying the nature of indicators along the process itself, it is by categorizing the indicators as either input or output indicators. Input indicators usually represent the resources used in order to generate a certain level of output. in the case of LGUs, they can be in the form of various levels of expenditure for a category or a specific municipal service (personnel expenditure, expenditure of goods \& services, capital expenditure), while output can be any indicator that reflects the level of any service offered by LGUs (number of people receiving water and sanitation, the number of students enrolled in primary education, etc). There are plenty of studies that show various input or output indicators in their particular municipal contest and availability of data (Jorge, Camoes, Carvalho, \& Fernandes, 2006); (Maria T. Balaguer-Coll D. P.-J.-B., 2002); (Karbowniki \& Kula).

Referring to the above, the context of our assessment requires a list of indicators that refer to the efficient use of the municipal resources, meaning their relationship input-output. in a number of studies related to the performance assessment of LGUs or municipalities there is a great list of indicators that could be applied (see Table 1). However, their usage is directly dependent on the availability of the data.

Table 1: List of Input and Output Indicators used in Efficiency Performance of LGUs

Source: Combination from various studies especially (Kalb, Geys, \& Heinemann, 2010, p. 8)

The list of financial indicators for LGUs

From the literature and the context of performance in the case of LGUs performance in Macedonia the following indicators can be used in order to judge and rank municipalities financial performance.

Diagram 3 A List of Financial Indicators for LGUs in Macedonia

\begin{tabular}{|c|c|c|}
\hline \multicolumn{3}{|c|}{ LGU Indicators } \\
\hline $\begin{array}{l}5 \text { Synthetic/composed indicators: } \\
\text { Tax revenues to Total revenues; } \\
\text { Non-Tax revenues to Total revenues; } \\
\text { Capital Income to Total revenues; } \\
\text { Transfers and Donations to Total } \\
\text { revenues; } \\
\text { Total Grants to Total Revenues }\end{array}$ & $\begin{array}{l}5 \text { Analytical indicators of revenues: } \\
\text { Total Revenues per capita; } \\
\text { Tax Revenue per capita; } \\
\text { Non-tax revenue per capita; } \\
\text { Capital income per capita; } \\
\text { Transfers and donations per capita }\end{array}$ & $\begin{array}{l}10 \text { Analytical indicators of } \\
\text { expenditures - } \\
\text { Total Expenditures per capita; } \\
\text { Total Wages and Salaries and } \\
\text { contributions per capita; } \\
\text { Total Goods and services per capita; } \\
\text { Total Capital Expenditures per capita; } \\
\text { Total Reserves and Other } \\
\text { Expenditures per capita; } \\
\text { Total Social Benefits per capita; } \\
\text { Total Wages and Salaries and } \\
\text { contributions per employee; } \\
\text { Total Goods and services per } \\
\text { employee; } \\
\text { Total Wages and Salaries and } \\
\text { contributions of the mayor; } \\
\text { Total Expenditures per Municipal } \\
\text { Council Member }\end{array}$ \\
\hline
\end{tabular}

\section{Conclusion}

This paper attempts to show a more detailed approach towards establishing a system of indicators (financial) indicators that can be used to evaluate the (financial) performance of local government units in the Republic of Macedonia. Most of the studies focused on evaluating performance do not give an extended foundation on which the system of indicator is generated. Therefore, this study contributed in this aspect. However, it is important to note that the first part of the literature review is based mainly in the reports and analysis of indicators proving a framework for performance assessment, while 
the second part is focused on various studies carried by scholars and writers of the field of financial performance analysis, mainly those evaluating the efficiency performance of municipalities across the world.

This paper should raise further research to those that are interested in using indicators for evaluating certain performance, and additionally, it should serve as a pushing factor to all local government stakeholders, especially government officials for the need of collecting data and provide them to the public regarding their financial performance.

\section{Bibliography}

[1] AC4SC. (2011). Equal Access Participatory and Evaluation Toolkit: Module2 - Setting Objectives and Indicators. Assessing Communication for Social Change.

[2] Afonso, A., \& Fernandes, S. (2003). Efficiency of Local Government Spending: Evidence for the Lisbon Region. Retrieved 2012, from https://www.repository.utl.pt/bitstream/10400.5/2732/1/wp92003.pdf

[3] Afonso, A., \& Fernandes, S. (2003). Efficiency of Local Government Spending: Evidence from Lisbon Region. Retrieved from https://www.repository.utl.pt/bitstream/10400.5/2732/1/wp92003.pdf

[4] Alfonso, A., \& Fernandes, S. (2005, November). Assessing and Explaining the Relative Efficiency of Local Government: Evidence from Portugese Municipalities. Retrieved from https://www.repository.utl.pt/bitstream/10400.5/2694/1/wp192005.pdf

[5] Brown, K. W. (1993, December). The 10-Point Test of Financial Condition: Towards ans Easy-To-Use Assessment Tool for Smaller Cities. Government Finance Review.

[6] CDKBC. (2012). Smart City Study: International study on the situation of ICT, innovation and Knowledge in cities. Bilbao: The Committee of Digital and Knowledge-based Cities of UCLG.

[7] Charnes, A., Cooper, W., \& Rhodes, a. E. (1978). Measuring the Efficiency of Decision Making Units. European Journal of Operational Research, 2, 429-444.

[8] Church, C., \& Rogers, M. (n.d.). Design for Results: Integrating Monitoring and Evaluation in Conflict Transformation Programs. Search for Common Ground. Retrieved from http://www.sfcg.org/Documents/dmechapter4.pdf

[9] Coelho, M. C., \& Watt, P. (n.d.). The Efficiency Of English Local Governments. Retrieved from http://webh01.ua.ac.be/pubsector/madrid/papers/paper\%20coelho\%20watt.doc.

[10] Devjak, S., Alves, J., Ribeiro, N., Monte, A., \& Fernandes, P. (2009). Quantitative Analysis of Financial Indicators: A Quantitative Analysis. Revista Enfoques: Cienca Politika y Administracion Publica, vol. VII, num. 11.

[11] DGFARD. (2006). Rural Development 2007-2013: Handbook on Common Monitoring and Evaluation Framework. Directorate General for Agriculture and Rural Development. Retrieved from http://ec.europa.eu/agriculture/rurdev/eval/guidance/document_en.pdf

[12] GFOA. (2000). Recommended Budget Practices:A Framework for Improved State and Local Government Budgeting. Chicago: National Advisory Council on State and Local Budgeting, Government Finance Officers Association.

[13] IOM. (2008). Handbook on Performance Indicators for Counter-Trafficing Projects. International Organization for Migration. Retrieved from http://www.iom.int/jahia/webdav/shared/shared/mainsite/published_docs/brochures_and_info_sheets/pi_hand book_180808.pdf

[14] Jackson, P. (2012). Value for money and international development: Deconstructing myths to promote a more constructive discussion. OECD Development Co-operation Directorate.

[15] James, O., \& Moseley, A. (2014). Does Performance Information About Public Services Affect Citizens' Perceptions, Satisfaction, and Voice Behaviour? Field Experiments With Absolute and Relative Performance Information. 2014 John Wiley \& Sons Ltd.

[16] Jorge, S. M., Camoes, P. J., Carvalho, J. B., \& Fernandes, M. J. (2006). Portugese Local Government Relative Efficiency: A DEA Approach. Hamburgh, Germany: 8th CIGAR Workshop on Performance Measurement and Output Budgeting in the Public Sector.

[17] Jurak, A. P., \& Pinteric, U. (n.d.). Assessment of Municipalities' Performance in Slovenia. Transylvanian Review of Administrative Sciences,, No. 35 E/2012, pp. 121-137. 
[18] Karbowniki, B., \& Kula, G. (n.d.). Efficiency of public sector at the level of local governments in Poland. Retrieved 2014, from http://www.eefs.eu/conf/Warsaw/Papers/634.pdf

[19] Kuhlmann, S. (2010). Performance Measurement in European local governments: a comparative analysis of reform experiences in Great Britain, France, Sweden and Germany. International Review of Administrative Sciences, 332-345. doi:10.1177/0020852310372050

[20] Liu, W. B., Chen, Z. L., Mingers, J., \& Q Li, W. M. (2009). The 3E Methodology for Developing Performance Indicators for Public Sector Organisations. Working Paper Series, Kent Business School.

[21] Maria T. Balaguer-Coll, D. P.-A. (2004). On the Determinants of Local Government Performance: A Two Stage Nonparametric Approach. (S. Instituto Valenciano de Investigaciones Económicas, Ed.) WP-EC 2004-04.

[22] Maria T. Balaguer-Coll, D. P.-J.-B. (2002). Efficiency and Quality in Local Government Management. The Case of Spanish Local Authorities. Barcelona: Documents de treball núm. 2/2002, Universitat Autonoma de Barcelona.

[23] Martin, M., \& Sauvageot, C. (2011). Constructing an indicator system or scorecard for higher education: A practical guide. Paris: UNESCO and International Institute for Educational Planning. Retrieved from http://www.uis.unesco.org/Library/Documents/constructing-indicator-system-scorecard-higher-education-2011en.pdf

[24] MDF. (2005). MDF Tool: Indicators. Management for Development.

[25] MLE. (2013). Measuring Success Toolkit: Indicators. The Measurement, Learning \& Evaluation Project.

[26] MOF. (2009). First Strategy of the Republic of Macedonia, 2010-12. Skopje: Ministry of Finance, Republic of Macedonia.

[27] Monkam, N. F. (2011). Local Municipality Productive Efficiency and Its Determinants in South Africa. Department of Economics Working Paper Series, University of Pretoria, Working Paper 2011-20.

[28] Mujeri, M. K. (n.d.). The Use of Qualitative and Quantitative Indicators for Local-Level Poverty Assessment: The Experience of a Pilot Survey in Bangladesh. UNDP. Retrieved from http://www.utoronto.ca/mcis/q2/papers/llI_Mujeri.pdf

[29] NBRM. (2014). Basic Economic Data. Skopje: National Bank of Republic of Macedonia. Retrieved from http://www.nbrm.mk/?ttemID=89A26FA4B8AA8F4CA6CF243F984FF307

[30] NPMAC. (2010). A Performance Management Frameworkfor State and Local Government: From Measurement and Reporting to. Chicago: National Performance Management Advisory Commission.

[31] SFCG. (n.d.). Indicator Module. Search for Common Ground and UKaid.

[32] UNDP. (2002). Handbook on Planning, Monitoring and Evaluating for Development Results. United Nations Development Programme.

[33] UNESCO. (2000). Systematic Monitoring of Education for All: Module A3. United Nations Educational, Scientific, and Cultural Organization. Retrieved from http://www4.unescobkk.org/education/efatraining/module-a3/1purpose-and-expected-learning-outcomes/\#sec11

[34] UNICEF. (n.d.). UNICEF M\&E Training Resource. UNICEF.

[35] Victoria, P. R. (2010). Strategic Management: Guideline, Version Number: 1.0, PROS 10/10. Victoria: Public Record Office Victoria. Retrieved from http://prov.vic.gov.au/wp-content/uploads/2011/05/1010g3.pdf

[36] Westhuizen, G. v., Dollery, B., \& Grant, B. (n.d.). An Efficiency Analysis of Basic Service Provision in South African Local Governemtn (2006/7 and 2008/9). TD The Journal of Transdisciplinary Research in Souther Africa, 8(2), pp. 268-282.

[37] Wilson, J. (1999). Financial Management for the Public Services. Philadelphia, USA: Open University Press. Retrieved from http://mcgraw-hill.co.uk/html/0335198457.html 